\title{
Screening of Chemical Characterization, Antifungal and Cytotoxic Activities of Essential Oil Constituents of Tagetes erecta L. from Erbil, Kurdistan Region-Iraq
}

\author{
Ausama Abdulwahab Safar ${ }^{1,2 *}$, Anwar Othman Ghafoor ${ }^{1}$, Dara Dastan $^{3}$ \\ ${ }^{1}$ Department of Biology, College of Education, Salahaddin University - Erbil, Kurdistan Region - Iraq \\ ${ }^{2}$ Plant Production Department, Khabat Technical Institute, Erbil Polytechnic University, Kurdistan Region -Iraq \\ ${ }^{3}$ Department of Pharmacognosy, School of Pharmacy, Medicinal Plants and Natural Products Research Center, \\ Hamadan University of Medical Sciences, Hamadan, Iran
}

Received: 27 May 2019

Accepted: 10 July 2019

\begin{abstract}
Ethnopharmacologic relevance: The history of health benefits of Tagetes (Asteraceae) dates back at least to the $12^{\text {th }}$ century. Tagetes erecta, an important specie from this genus, was widely known for its traditional medicine. Different parts of $T$. erecta are used in folk medicine to cure various types of diseases.

Aim of the study: Considering the lack of scientific studies of Tagetes, the present study was aimed to evaluate the chemical composition, antifungal activity of its essential oil against fungi responsible for human infections, as well as its cytotoxicity on HepG2 human liver carcinoma cell lines.

Materials and methods: Clevenger-type was performed to hydrodistillate EOs and chemically analyzed by combination of GC and MS technique, followed by the evaluation of antifungal activity by using the broth microdilution method. The cytotoxicity was evaluated through MTT assay against HepG2 and expressed as $\mathrm{IC}_{50}$.

Results: One hundred and eleven compounds of the total EOs were identified from three parts (shoot, flower, and root). For the first time, more than 60 new compounds such as iso-bergapten, bergapten, (3)-thujanol acetate, sylvestrene, $\alpha$-vetivone, tridecenol acetate, $\beta$-atlantol, and p-cymenene have been isolated from T. erecta. Among all yeasts, C. albicans was the most sensitive with MICs of 0.08, 0.04, $0.16 \mu \mathrm{L} \mathrm{mL}^{-1}$ for TES, TEF, and TER oil respectively. In addition, maximum apoptosis rate of up to $90 \%$ was observed for HepG2 cell line at concentrations ranging between 82 and $122 \mu \mathrm{g} / \mathrm{ml}$, with $\mathrm{IC}_{50}$ value from $11.58 \mu \mathrm{g} \mathrm{mL}^{-1}$ to $19.86 \mu \mathrm{g} \mathrm{mL}^{-1}$

Conclusion: The findings from this study showed that the chemical composition of $T$. erecta EO varies, depending on the geographical situation, extraction method, environmental factors, and plant
\end{abstract}

*e-mail: allelopathy.81@gmail.com ausama.safar@epu.edu.iq 
organ. Our results also support the hypothesis that the antifungal capacity and cytotoxic activity of the EOs can be ascribed to the lipophilic nature and low molecular weights of the constituents of EOs.

Keywords: Tagetes erecta, essential oil, GC-MS, new terpenoids, antifungal, cytotoxicity

\section{Introduction}

The Aztec marigold T. erecta L. (Asteraceae) family and was widely known as an ornamental plant in the Kurdistan region, as well as being used in different fields like cosmetic preparation and medicine. A literature survey revealed that $T$. erecta possesses a wide spectrum of phytochemical constituents that are used as remedies to treat various health problems, including piles, wounds, fevers, stomachic, rheumatism, scabies and liver troubles, and is also utilized for eye treatments [1]. However, one of the most complex mixture components in $T$. erecta is the essential oil with volatile and aromatic properties, which exhibit effective pharmacological activities like anti-inflammatory [2], insecticidal [3], larvicidal [4], antimicrobial [5], antioxidant [6], anticancer [7], as well as allelopathy efficacy [8]. The present study has been undertaken to isolate the EO from TES, TEF, and TER parts of $T$. erecta using the GC-MS technique, and to evaluate their antifungal and cytotoxic activities. However, this is the first publication to provide a list of more than 60 new compounds, which will be discussed in the following sections.

\section{Materials and Methods}

\section{Plant Material and Isolation of Essential Oils}

The three different parts of T. erecta (shoot (TES), flower (TEF), and root (TER)) were sampled fresh every morning in fresh polythene bags, then cut into small pieces and prepared for distillation. A voucher specimen was deposited at the herbarium of Salahaddin University- Hawler under voucher No. 7592. Seven hundred grams of fresh plant parts were submitted to hydrodistillation for 3 hours using a Clevenger-type apparatus to produce oil under laboratory conditions. The oil produced was dried over anhydrous sodium sulfate ${ }^{1}\left(\mathrm{Na}_{2} \mathrm{SO}_{4}\right)$ and stored in tightly closed dark vials at $4^{\circ} \mathrm{C}$ until analysis [8].

\footnotetext{
Anhydrous sodium sulfate $\left(\mathrm{Na}_{2} \mathrm{SO}_{4}\right)$ is typically used in organic chemistry as a drying agent. After aqueous extractions, the organic layer always has a certain amount of water left in it. Adding anhydrous sodium sulfate removes this water by forming sodium sulfate hydrate, which conveniently is also a solid, allowing it to be filtered away. Magnesium sulfate (MgSO4) is a similar drying agent.
}

\author{
Identification of Compounds by Gas \\ Chromatography (GC) and Gas \\ Chromatography-Mass Spectrometry (GC/MS)
}

The identity and quantity of particular components of $T$. erecta essential oil were evaluated by the GC-MS analysis method using a Thermoquest-Finnigan gas chromatograph GC equipped with Trace MS detector and fused silica capillary DB-5 column (60 m $90.25 \mathrm{~mm}$; film thickness $0.25 \mu \mathrm{m}$ ). The measurement records started after $3 \mathrm{~min}$ of the run began. The oven temperature was programmed from 60 to $250^{\circ} \mathrm{C}$ at the rate of $5^{\circ} \mathrm{C} / \mathrm{min}$. and finally a the temperature of $250^{\circ} \mathrm{C}$ was kept constant for 10 minutes. Subsequent GC working conditions were as follows: carrier gas was nitrogen with a constant flow rate of $1 \mathrm{~mL} / \mathrm{min}$. Ionization voltage was kept at $70 \mathrm{eV}$. MS working conditions were as follows: temperature of the ion source and the interface were 200 and $250^{\circ} \mathrm{C}$, respectively, the mass range was scanned from 43 to $456 \mathrm{~m} / \mathrm{z}$. The injector and detector temperatures were 250 and $300^{\circ} \mathrm{C}$, respectively [9].

The constituents were identified by calculation of their retention indices under the same chromatographic conditions for n-alkanes $\left(\mathrm{C}_{6}-\mathrm{C}_{24}\right)$ and the oil on a DB-5 column. Compounds were identified by comparing their mass spectra library (Wiley and Adams) or with authentic compounds, and for confirmed compounds their GC retention indices were compared with authentic compounds or with those reported $[9,10]$. Each sample was then analyzed three times with GC-FID to obtain the percentage concentration of each constituent without performing any correction.

\section{Antifungal Broth Microdilution Susceptibility Testing}

The effectiveness of the antifungal activities of the tested essential oils was evaluated using two-fold serial broth microdilution techniques as described by Pfaller and V. Chaturvedi [11], with some modification. Four Candida strains (C. albicans, C. glabrata, C. krusei, and $C$. tropicalis) were obtained from the Biology Department, College of Science, Salahaddin University, Erbil. 96 well flat-shaped microtitre culture plates were used. Stock solutions of EOs were prepared by dissolving the EOs in 5\% dimethyl sulphoxide (DMSO) at a ratio 1:10 to facilitate the dispersion of the oils in the aqueous nutrient medium. Plant EOs of $100 \mu \mathrm{l}$ from the stock solution $\left(10 \mu \mathrm{ml}^{-1}\right)$ were taken into the first well containing $100 \mu \mathrm{l}$ of sterile SDB and thoroughly mixed. Serial 11 -fold dilutions were performed by transferring $100 \mathrm{~mL}$ from well to well (on 
row). From the last well, $100 \mu$ l solution was discarded. Thus, the reached concentrations ranged from 5 to $0.005 \mu \mathrm{EO} / \mathrm{mL}$.

At the time of inoculation, the final concentrations of microbial cells were about $0.5-2.5 \times 10^{3} \mathrm{CFU} / \mathrm{ml}$ [12]. Then $20 \mu \mathrm{l}$ of test organisms were added into each tube. The final volume of the solution in each tube was made up to $220 \mu \mathrm{l}$. Nystatin (520 ppm) was used for control study. The absorbance for all 96 wells was measured at $630 \mathrm{~nm}$ before incubating by ELISA Reader (BioTech, USA). Then the plates were incubated under shaking conditions (100-120 rpm) at $25 \pm 2^{\circ} \mathrm{C}$ for 24 hours. After the incubation time, the absorbance was re-measured at the end of incubation to determine the final absorbance and compare it with the initial absorbance [13]. Each sample assay was carried out in triplicate.

\section{Cytotoxic Activity of the Essential Oils}

The cytotoxic activity of $T$. erecta EOs was screened by determination of their $\mathrm{IC}_{50} \mathrm{~s}$ using the (MTT) colorimetric in-vitro assay as described by Oliveira and Alves [7], with slight modifications. The liver (HepG2) cell line was obtained from the Pasteur Institute of Iran. In this study, $1 \times 10^{4}$ cells/well were seeded in 96 well plates with $90 \mu \mathrm{l}$ of DMEM medium supplemented with $10 \%$ fetal bovine serum (FBS) containing concentrations of the essential oils that ranged from 5 to $122 \mu \mathrm{g} / \mathrm{mL}$ and were incubated for 24 hours at $37^{\circ} \mathrm{C}$ in a $\mathrm{CO}_{2}$ incubator $(5 \%)$. Then, $10 \mu \mathrm{l}$ of MTT solution $(5 \mathrm{mg} / \mathrm{ml})$ was pipetted into each well and the mixture was incubated for 4 hours at $37^{\circ} \mathrm{C}$. After incubation, $100 \mu \mathrm{l}$ of (DMSO) was added to each well to dissolve the formed formazan from the MTT and incubated overnight at $37^{\circ} \mathrm{C}$. Absorbance was then measured at a wavelength of $540 \mathrm{~nm}$ and a reference length of $690 \mathrm{~nm}$ using the ELISA reader (BioTech, USA). Untreated cells $(<1 \%$ DMSO) were used as control. The percentage of the reduction of viability was calculated as follows:

$$
\text { Viability } \%=\frac{O D_{s}}{O D_{C}} \times 100
$$

...where ODs is the mean value of the measured optical density of the $100 \%$ extracts of the sample and ODc is the mean value of the measured optical density of the control [14].

Five replicate wells were used for each concentration tested, and $50 \%$ inhibition of cell growth $\left(\mathrm{IC}_{50}\right)$ was used as the analysis parameter.

\section{Statistical Analysis}

Results are presented as the mean \pm standard deviation. The one-way ANOVA and Dunnett's multiple comparisons were used to test the significance of the difference between two mean values. $\mathrm{P}<0.01$ was considered to indicate a statistically significant difference. The half maximal inhibitory concentrations $\left(\mathrm{IC}_{50}\right)$ were statistically analysed by GraphPad Prism 6 for Windows software package.

\section{Results and Discussion}

\section{The Common Volatile Oils of $T$. erecta}

The variation in essential oil content and composition of TES, TEF, and TER of T. erecta growing in Erbil was analyzed using GC-MS and a GC- flame ionization detector (GC-FID). The identified constituents with their relative content in EOs are summarized in Table 1. Maximal EO content $(0.64 \%)$ was obtained from TES, followed by TEF $(0.48 \%)$, and minimal by TER $(0.2 \%)$. There were 62,56 , and 43 compounds identified from TES-EO, TEF-EO, and TER-EO comprising 93.87\%, $90.83 \%$, and $93.22 \%$ of the total oil, respectively.

The TES and TEF oil composition was mainly dominated by monoterpenoids $75 \%$ and $71 \%$ consecutively, representing piperitone (11.58\%, $7.5 \%$, piperitenone $(8.36 \%, 11.22 \%)$, sylvestrene $(5.9 \%, 6.82 \%)$, terpinolene $(2.97 \%, 5.41 \%)$, and $(Z)-\beta$ ocimene $(2.46 \%, 3.97 \%)$ and their major constituents respectively. The second major class of compounds in both parts were sesquiterpenoids, with percentages of $22 \%$ and $20 \%$ respectively, from which (E)caryophyllene $(5.92 \%, 7.72 \%)$, caryophyllene oxide $(4 \%$, $2.87 \%)$, (E)-myroxide $(3.57 \%, 5.41 \%)$, and spathulenol $(1.31 \%, 1.78 \%)$ were the most abundant consecutively. The results have shown similarity with the composition reported by Marques, Morais [4], Oliveira, Alves [7], Laosinwattana, Wichittrakarn [8], Crevelin [15], Resmi, and Nair [16], who emphasized that the monoterpenes are the predominant components of the aerial parts of T. erecta ranging between ( $46.3 \%$ to $97.3 \%$ ), besides some variation in major and minor compounds occurred. Furthermore, major compounds such as methyleugenol (E)-ocimene, undacane, piperitenone oxide, l-limonene, cis-ocimene, (E)-ocimene, limonene, (Z)-myroxide, camphene, $\alpha$-terpinolene, $\alpha$-thujene, 1,4-naptoquinone, 2-hexyl-1-decanol, fenchol, eugenol, and 4-terpinyl acetate isolated by Tripathi, Bhatia [5], Oliveira, Alves [7], Crevelin [15], Resmi, Nair [16], Yasheshwar, and Umar [17] were not found in our analysis.

Conversely, the chemical constituents of TER-EO were quite different from the components of the TES and TEF oil, which were characterized by a large number of furanocoumarins, non-volatile compounds, accounting for $59 \%$ of the total root oil composition. The second major groups of compounds were sesquiterpenoids, from which cyperene $(9.64 \%)$, caryophyllene oxide (4.17\%), (E)- $\beta$-farnesene (2.95), $\alpha$-vetivone (2.83), and $\beta$-bisabolene (2.5) were the most abundant, meanwhile monoterpenes were occupied by only a few amounts of TER-EO representing 3\% of the total oil. Worth 
Table 1. Essential oil composition of different parts of T. erecta L. from Erbil.

\begin{tabular}{|c|c|c|c|c|c|c|c|c|}
\hline \multirow{2}{*}{$\#$} & \multirow{2}{*}{ Compounds } & \multirow{2}{*}{$\mathrm{RI}^{\mathrm{a}}$} & \multicolumn{2}{|c|}{ TES } & \multicolumn{2}{|c|}{ TEF } & \multicolumn{2}{|c|}{ TER } \\
\hline & & & $\mathrm{RT}^{\mathrm{b}}$ & $\%$ & RT & $\%$ & RT & $\%$ \\
\hline 1. & $\alpha$-Pinene & 932 & 4.09 & 0.14 & 4.09 & 0.34 & & \\
\hline 2. & Sabinene & 969 & 4.77 & 0.61 & 4.76 & 0.9 & & \\
\hline 3. & Myrcene & 988 & 5.05 & 0.29 & 5.05 & 0.19 & & \\
\hline $4 .^{*}$ & (3E)-Hexenyl acetate & 1001 & 5.36 & 0.07 & & & & \\
\hline 5. & $\alpha$-phellandrene & 1002 & & & 18.93 & 0.1 & & \\
\hline 6. & O-Cymene & 1022 & 5.78 & 0.32 & 5.77 & 0.31 & & \\
\hline 7. & Limonene & 1024 & & & & & 5.88 & 0.07 \\
\hline $8 . *$ & Sylvestrene & 1025 & 5.87 & 5.9 & 5.88 & 6.82 & & \\
\hline 9. & (Z)- $\beta$-Ocimene & 1030 & 6.02 & 2.46 & 6.03 & 3.97 & & \\
\hline 10. & (E)- $\beta$-Ocimene & 1044 & 6.24 & 0.5 & 6.24 & 0.42 & & \\
\hline 11. & dihydro-Tagetone & 1046 & 6.34 & 0.38 & 6.34 & 0.89 & & \\
\hline $12 .^{*}$ & cis-Linalool oxide & 1067 & & & 6.91 & 0.25 & & \\
\hline 13. & Terpinolene & 1086 & 7.2 & 2.97 & 7.21 & 5.41 & & \\
\hline $14 .^{*}$ & p-Cymenene & 1089 & 7.26 & 2.96 & 7.25 & 0.89 & & \\
\hline 15. & Linalool & 1095 & 7.48 & 0.91 & 7.47 & 0.42 & & \\
\hline $16 .^{*}$ & $\alpha$-Pinene oxide & 1099 & 7.4 & 0.21 & 7.39 & 0.13 & & \\
\hline 17. & 1,3,8-p-Menthatriene & 1108 & 7.79 & 0.18 & & & & \\
\hline $18 .^{*}$ & $(2 \mathrm{E}, 4 \mathrm{E})$-Octadienol & 1113 & 7.81 & 0.3 & 7.8 & 0.54 & & \\
\hline $19 .^{*}$ & dehydro-Sabina ketone & 1117 & & & & & 8.13 & 0.05 \\
\hline 20. & (Z)-Epoxy-ocimene & 1128 & 8.24 & 1.5 & 8.23 & 1.69 & & \\
\hline $21 *^{*}$ & trans-Pinocarveol & 1135 & 8.40 & 0.79 & 8.38 & 0.32 & & \\
\hline 22. & (E)-Tagetone & 1139 & 8.59 & 1.87 & 8.57 & 2.29 & & \\
\hline 23. & (E)-Myroxide & 1140 & 8.5 & 3.57 & 8.47 & 1.13 & & \\
\hline 24. & (Z)-Tagetone & 1148 & 8.79 & 0.8 & 8.78 & 1.6 & & \\
\hline 25. & Borneol & 1165 & 9.18 & 0.21 & & & & \\
\hline 26. & Terpinen-4-ol & 1174 & 9.44 & 0.65 & & & & \\
\hline 27.* & (E)-Isocitral & 1177 & 9.39 & 0.33 & 9.39 & 0.3 & & \\
\hline 28. & p-cymen-8-ol & 1179 & 9.77 & 6.15 & 9.72 & 5.46 & & \\
\hline $29 .^{*}$ & p-methyl-Acetophenone & 1179 & 9.71 & 2.34 & & & & \\
\hline $30 .^{*}$ & cis-Pinocarveol & 1182 & & & 9.42 & 0.56 & & \\
\hline 31. & $\alpha$-Terpineol & 1186 & 9.84 & 1.16 & & & & \\
\hline $32 .^{*}$ & Verbenol & 1197 & 10 & 0.26 & & & & \\
\hline $33 . *$ & cis-4-Caranone & 1200 & 10.1 & 0.7 & & & & \\
\hline 34. & Verbenone & 1204 & & & 9.77 & 0.43 & & \\
\hline 35. & (Z)-Ocimenone & 1226 & & & 10.81 & 3.45 & & \\
\hline $36 .^{*}$ & cis-p-Mentha-1(7),8-dien-2-ol & 1227 & 10.59 & 0.18 & & & & \\
\hline 37. & (E)-Ocimenone & 1235 & 10.82 & 1.34 & 11.02 & 2.13 & & \\
\hline $38 .^{*}$ & Carvacrol, methyl ether & 1241 & 10.84 & 0.55 & & & & \\
\hline 39. & Car-3-en-2-one & 1244 & 11.04 & 0.97 & & & & \\
\hline 40. & Piperitone & 1249 & 11.49 & 11.58 & 11.45 & 7.5 & & \\
\hline $41 .^{*}$ & Perilla aldehyde & 1269 & & & 11.82 & 0.29 & & \\
\hline 42. & Isobornyl acetate & 1283 & & & 12.17 & 1.32 & & \\
\hline
\end{tabular}


Table 1. Continued.

\begin{tabular}{|c|c|c|c|c|c|c|c|c|}
\hline $43 .^{*}$ & perilla alcohol & 1294 & & & 12.33 & 0.42 & & \\
\hline $44 . *$ & 3-Thujanol acetate & 1295 & 12.35 & 11.58 & & & & \\
\hline 45. & Carvacrol & 1298 & 12.68 & 0.23 & & & & \\
\hline $46 .^{*}$ & (Z)-Patchenol & 1316 & 12.93 & 0.27 & & & & \\
\hline 47.* & iso-Dehydro carveol acetate & 1326 & 13.44 & 0.15 & & & & \\
\hline 48. & Piperitenone & 1340 & 13.74 & 8.36 & 13.72 & 11.22 & & \\
\hline 49. & $\alpha$-Longipinene & 1350 & 13.85 & 1.31 & 13.83 & 0.59 & & \\
\hline 50. & Piperitenone oxide & 1366 & 14.31 & 0.52 & 14.3 & 2.67 & & \\
\hline $51 .^{*}$ & Longicyclene & 1371 & & & & & 14.21 & 0.58 \\
\hline $52 *$ & $\alpha$-Copaene & 1374 & & & & & 14.46 & 0.05 \\
\hline 53. & Geranyl acetate & 1379 & 14.64 & 0.14 & 14.62 & 0.17 & & \\
\hline 54. & $\beta$-Elemene & 1389 & & & & & 14.89 & 0.35 \\
\hline $55 .^{*}$ & (Z)-Jasmone & 1392 & 15.07 & 0.19 & 15.06 & 0.23 & & \\
\hline 56. & Cyperene & 1398 & & & & & 15.13 & 9.64 \\
\hline $57 .^{*}$ & $\alpha$-Funebrene & 1402 & 15.16 & 0.23 & 15.14 & 0.23 & & \\
\hline 58. & (Z)-Caryophyllene & 1408 & 15.29 & 0.71 & 15.27 & 0.3 & 15.25 & 0.08 \\
\hline 59. & (E)-Caryophyllene & 1417 & 15.61 & 5.92 & 15.59 & 7.72 & 15.57 & 1.88 \\
\hline $60 .^{*}$ & $\alpha$-trans-Bergamotene & 1432 & & & & & 21.56 & 0.76 \\
\hline 61. & Aromadendrene & 1439 & 16.28 & 0.12 & & & 16 & 0.59 \\
\hline 62. & (E)- $\beta$-Farnesene & 1454 & 16.44 & 0.79 & 16.42 & 0.99 & 16.44 & 2.95 \\
\hline $63 .^{*}$ & dehydro Aromadendrane & 1460 & 16.56 & 0.19 & 16.53 & 0.11 & & \\
\hline $64 .^{*}$ & $\gamma$-Gurjunene & 1475 & & & & & 16.98 & 0.28 \\
\hline 65. & Germacrene D & 1484 & 17.09 & 0.16 & 17.08 & 0.5 & 17.15 & 1.92 \\
\hline $66 .^{*}$ & $\beta$-Selinene & 1489 & & & & & 17.26 & 0.03 \\
\hline $67 .^{*}$ & $\alpha$-Selinene & 1498 & & & & & 17.42 & 0.22 \\
\hline 68. & Bicyclogermacrene & 1500 & & & 17.45 & 0.12 & & \\
\hline $69 .^{*}$ & $\gamma$-Patchoulene & 1502 & & & & & 17.53 & 0.43 \\
\hline $70 .^{*}$ & $\beta$-Bisabolene & 1505 & & & & & 17.72 & 2.5 \\
\hline 71. & $(\mathrm{E}, \mathrm{E})-\alpha$-Farnesene & 1505 & & & 17.66 & 0.45 & & \\
\hline $72 .^{*}$ & trans-Cycloisolongifol-5-ol & 1513 & & & & & 17.98 & 0.5 \\
\hline 73. & $\beta$-Sesquiphellandrene & 1521 & & & & & 18.07 & 0.19 \\
\hline $74 . *$ & Italicene epoxid & 1547 & 18.81 & 0.29 & 18.79 & 0.34 & 18.78 & 0.38 \\
\hline 75. & (E)-Nerolidol & 1561 & 19.04 & 0.82 & 19.02 & 0.6 & & \\
\hline $76 .^{*}$ & epi-Longipinanol & 1562 & 18.96 & 0.1 & 5.36 & 0.1 & & \\
\hline 77. & Spathulenol & 1577 & 19.47 & 1.31 & 19.43 & 1.78 & & \\
\hline 78. & Caryophyllene oxide & 1582 & 19.56 & 4 & 19.52 & 2.87 & 19.54 & 4.17 \\
\hline 79.* & Fokienol & 1596 & & & & & 19.79 & 0.06 \\
\hline $81 .^{*}$ & Caryophylla-4(12),8(13)-dien-5 $\alpha$-ol & 1639 & 20.8 & 0.51 & & & 20.77 & 0.89 \\
\hline 82.* & Selina-3,11-dien-6 $\alpha$-ol & 1642 & & & 20.78 & 0.41 & & \\
\hline $83 .^{*}$ & Himachalol & 1652 & 21.18 & 0.11 & & & & \\
\hline $84 .^{*}$ & 14-hydroxy-(Z)-Caryophyllene & 1666 & & & & & 21.29 & 0.63 \\
\hline $85 .^{*}$ & 14-hydroxy-9-epi-(E)-Caryophyllene & 1668 & 7.79 & 0.18 & & & 15.93 & 0.76 \\
\hline $86 .^{*}$ & 2Z,6Z-Farnesal & 1684 & & & & & 21.71 & 0.07 \\
\hline
\end{tabular}


Table 1. Continued.

\begin{tabular}{|c|c|c|c|c|c|c|c|c|}
\hline \multirow{2}{*}{$\#$} & \multirow{2}{*}{ Compounds } & \multirow{2}{*}{$\mathrm{RI}^{\mathrm{a}}$} & \multicolumn{2}{|c|}{ TES } & \multicolumn{2}{|c|}{ TEF } & \multicolumn{2}{|c|}{ TER } \\
\hline & & & $\mathrm{RT}^{\mathrm{b}}$ & $\%$ & RT & $\%$ & RT & $\%$ \\
\hline $88 .^{*}$ & Cyperotundone & 1695 & & & & & 22.06 & 0.08 \\
\hline $89 .^{*}$ & Tridecenol acetate & 1703 & & & & & 22.33 & 1.16 \\
\hline $90 .^{*}$ & cis-Thujopsenal & 1708 & & & & & 22.48 & 0.37 \\
\hline $91 .^{*}$ & (2E,6Z)-Farnesol & 1714 & & & & & 22.66 & 0.23 \\
\hline $92 . *$ & Isobicyclogermacrenal & 1733 & & & & & 22.93 & 0.05 \\
\hline $93 . *$ & (6S,7R)-Bisabolone & 1748 & & & & & 23.12 & 0.43 \\
\hline $94 . *$ & $\beta$-Acoradienol & 1762 & & & 24.69 & 0.35 & & \\
\hline $95 . *$ & $\beta$-Costol & 1766 & 25.45 & 0.12 & & & 23.54 & 0.21 \\
\hline $96 . *$ & $\beta$-Bisabolenal & 1768 & & & & & 23.73 & 0.25 \\
\hline 97.* & Squanmulosone & 1770 & & & & & 23.86 & 0.77 \\
\hline 98. & (E)- $\alpha$-Atlantol & 1777 & & & 29.55 & 0.31 & & \\
\hline 99.* & $\alpha$-Vetivone & 1842 & & & & & 25.56 & 2.83 \\
\hline $100{ }^{*}$ & Flourensadiol & 1869 & 26.83 & 0.12 & & & & \\
\hline 101. & Phytol & 1942 & 27.52 & 0.08 & 24.95 & 7.07 & & \\
\hline 102 . $^{*}$ & Columellarin & 1952 & & & & & 28.34 & 0.25 \\
\hline $103 . *$ & $2 \alpha$-acetoxy-Amorpha-4,7(11)-dien-8-on & 1985 & 34.24 & 0.37 & & & & \\
\hline 104.* & epi-Catalponol & 1988 & & & & & 28.82 & 0.24 \\
\hline $105 .^{*}$ & Phyllocladene & 2016 & & & & & 29.67 & 0.05 \\
\hline $106 . *$ & iso-Bergapten & 2033 & & & & & 26.87 & 41.84 \\
\hline 107.* & Bergapten & 2056 & & & & & 32.19 & 12.64 \\
\hline $108 .^{*}$ & n-Heneicosane & 2100 & & & 29.93 & 0.18 & & \\
\hline 109.* & (E)-phytol acetate & 2218 & 30.27 & 1.84 & 30.25 & 0.6 & & \\
\hline 110.* & Incensole oxide & 2279 & & & 30.75 & 0.13 & & \\
\hline 111. & Dotriacontane & 3400 & & & 33.42 & 0.32 & & \\
\hline & Total & & \multicolumn{2}{|c|}{$62(93.87 \%)$} & \multicolumn{2}{|c|}{$56(90.86 \%)$} & \multicolumn{2}{|c|}{$43(93.22 \%)$} \\
\hline & Monoterpene hydrocarbons & & \multicolumn{2}{|c|}{$17 \%$} & \multicolumn{2}{|c|}{$22 \%$} & \multicolumn{2}{|c|}{$<0.5 \%$} \\
\hline & Oxygenated Monoterpenes & & \multicolumn{2}{|c|}{$58 \%$} & \multicolumn{2}{|c|}{$49 \%$} & \multicolumn{2}{|c|}{$3 \%$} \\
\hline & Sesquiterpene hydrocarbons & & \multicolumn{2}{|c|}{$3 \%$} & \multicolumn{2}{|c|}{$3 \%$} & \multicolumn{2}{|c|}{$23 \%$} \\
\hline & Oxygenated Sesquiterpenes & & \multicolumn{2}{|c|}{$19 \%$} & \multicolumn{2}{|c|}{$17 \%$} & \multicolumn{2}{|c|}{$14 \%$} \\
\hline & Oxygenated diterpenes & & \multicolumn{2}{|c|}{$0 \%$} & \multicolumn{2}{|c|}{$8 \%$} & \multicolumn{2}{|c|}{$0 \%$} \\
\hline & Furanocoumarins & & \multicolumn{2}{|c|}{$0 \%$} & \multicolumn{2}{|c|}{$0 \%$} & \multicolumn{2}{|c|}{$59 \%$} \\
\hline & Others & & \multicolumn{2}{|c|}{$3 \%$} & & & & \\
\hline
\end{tabular}

a RI, Retention indices relative to C6 - C24 n-alkanes on the DB-5 column.

${ }^{\mathrm{b}} \mathrm{RT}$, Retention Time

* New chemical constituents

mentioning is that the thiophenes, which were isolated from the root part in other studies $[3,4,6,18]$, were absent in our analysis. When compared with the literature chart, the results obtained in this investigation showed that the chemical composition of the essential oils from different parts of $T$. erecta differ depending on the parts of the plant used, isolation method, and the environmental conditions.
The New Chemical Components

Analysis of the EOs reveals that they possess very complex GC-MS profiles. The new structures identified were mainly monoterpenoids in TES-EO (26.21\%) and TEF-EO (11.6\%), represented by monoterpene hydrocarbons $(8.86 \%, \quad 7.71 \%)$ and oxygenated monoterpenes $(17.35 \%, 3.89 \%)$ respectively (Table 1). 
The major constituents distributed in both parts were 3-thujanol acetate, sylvestrene, p-cymenene, p-methylacetophenone, and (E)-phytol acetate. Furthermore, the essential oil composition of TER was mainly dominated by non-volatile furanocoumarins represented by iso-bergapten $41.84 \%$ and bergapten $12.64 \%$, followed by terpenoids $\alpha$-vetivone $(2.83 \%), \beta$-bisabolene $(2.5 \%)$, tridecenol acetate $(1.16 \%)$, and $\beta$-atlantol $(1.03 \%)$.

\section{Antifungal Activity}

The antifungal efficacy of the EOs from different parts of $T$. erecta was tested against $C$. albicans, $C$. glabrata, C. krusei, and C. tropicalis (Fig. 1). The results of the MIC and the minimum fungicidal concentration (MFC) are given in Table 2. Statistically, T. erecta EO has restricted significantly all yeast growth compared with the positive control Nystatin (520 ppm). According to the classification of biological activity used by Saha and Kundu [19], and Pessini, Dias, and Filho [20], the antifungal activities were categorized as weak (above $1.6 \mu \mathrm{l} \mathrm{mL}-1)$, moderate $\left(0.6\right.$ to $\left.1.5 \mu \mathrm{mL}^{-1}\right)$ and strong (lower than $0.5 \mu \mathrm{m} \mathrm{mL}^{-1}$ ). Hence, a highly significant antifungal activity has been recorded for all the EOs with MIC value ranging from $\left(0.08 \mu \mathrm{ml}^{-1}\right)$ to $\left(0.32 \mu \mathrm{l} \mathrm{ml} \mathrm{m}^{-1}\right)$, with the exception of $C$. tropicalis, which was moderately affected by all EOs (MIC value $\left.1.25 \mu \mathrm{ml}^{-1}\right)$.

Hence, we found that among all the Candida species tested, C. albicans was the most affected fungi toward the EO of all $T$. erecta, while $C$. tropicalis was moderately affected. The results are consistent with those obtained by Resmi and Nair [16], and Padalia and Chanda [21]. Previously, the inhibitory activity of the EOs of other Tagetes species against Candida spp has already been confirmed [22-24]. As a result, this antifungal potential may be associated with the existence of lipophilic compounds, which could interfere with the cytoplasmic membrane depending on the presence of water-soluble terpenoids present in the essential oil [22]. a)

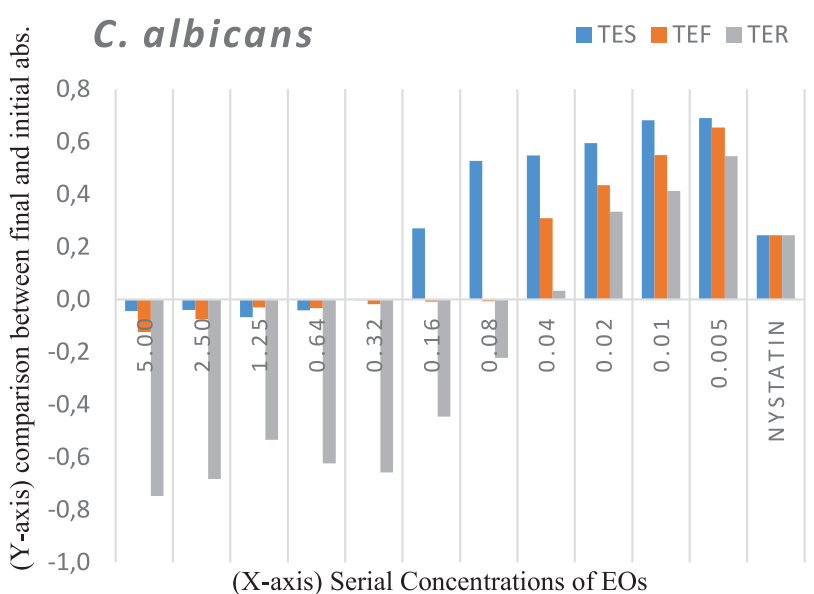

c)

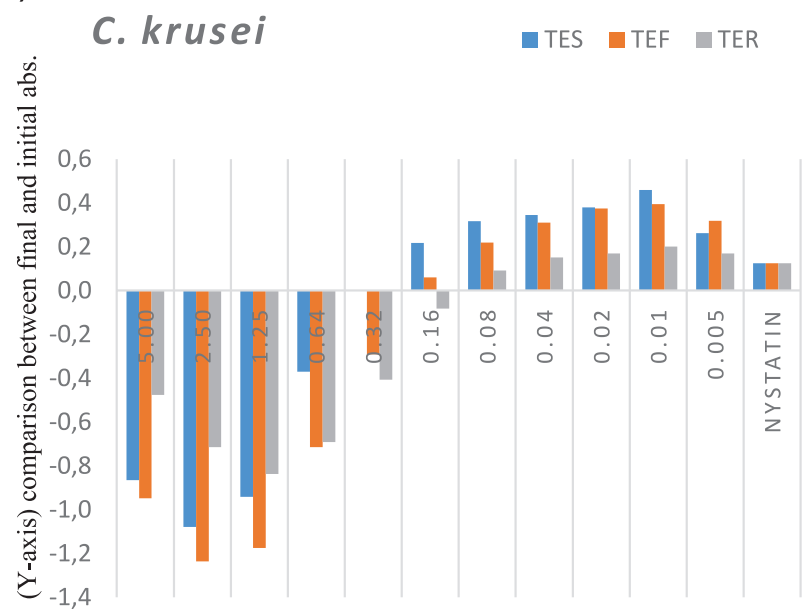

(X-axis) Serial Concentrations of EOs b)

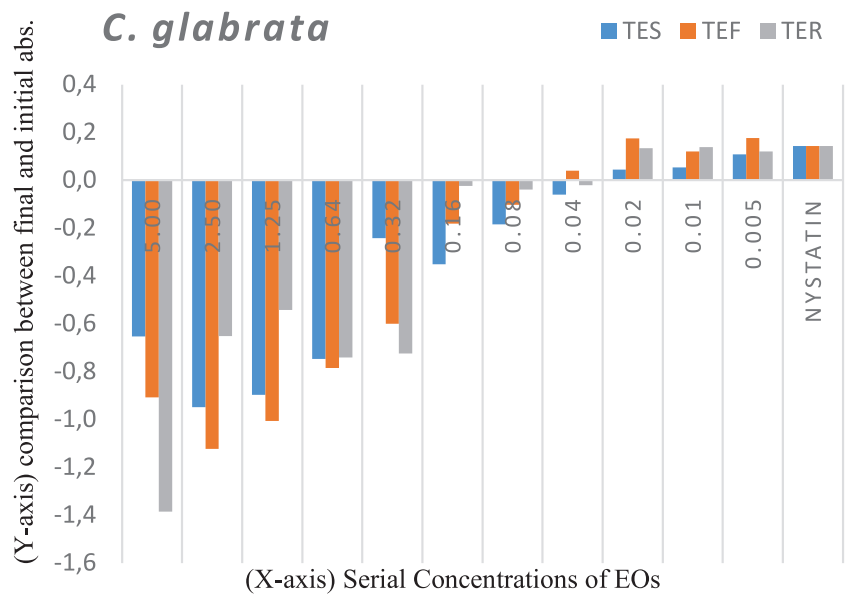

d)

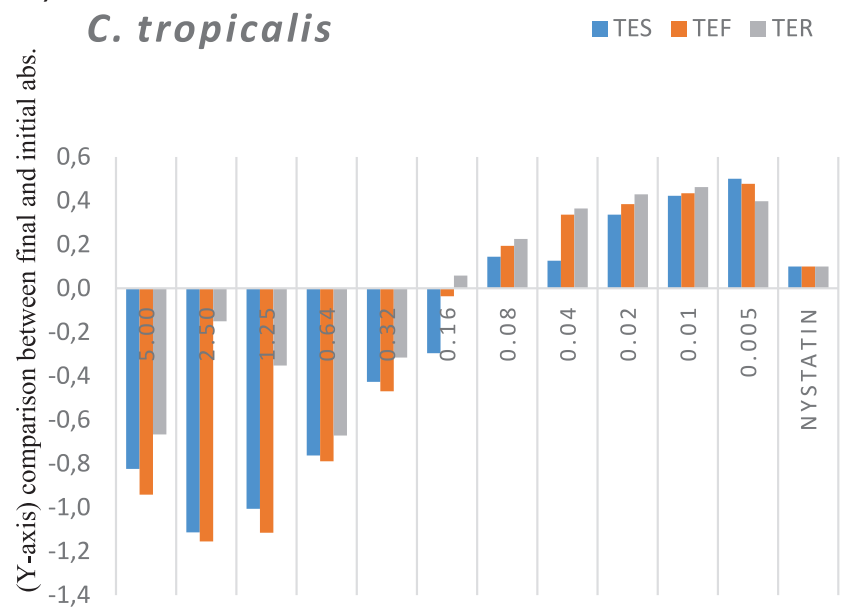

(X-axis) Serial Concentrations of EOs

Fig. 1. Antifungal effect of various concentrations $\left(\mu 1 \mathrm{ml}^{-1}\right)$ of EOs of three T. erecta parts on: a) C. albicans, b) C. glabrata, c) C. krusei, d) C. tropicalis. 
Table 2. Minimum inhibition concentration (MIC $\left.\left(\mu 1 \mathrm{ml}^{-1}\right)\right)$ and minimum fungal concentration $\left(\mathrm{MFC}\left(\mu 1 \mathrm{ml}^{-1}\right)\right)$ of $T$. erecta EOs against test fungi strains.

\begin{tabular}{|c|c|c|c|c|c|c|}
\hline \multirow{3}{*}{ Test Fungi } & \multicolumn{6}{|c|}{ EOs conc. $\left(\mu 1 \mathrm{ml}^{-1}\right)$} \\
\hline & \multicolumn{2}{|c|}{ Shoot } & \multicolumn{2}{|c|}{ Flowers } & \multicolumn{2}{|c|}{ Root } \\
\hline & MIC & MFC & MIC & MFC & MIC & MFC \\
\hline Candida albicans & 0.08 & 1.25 & 0.04 & 0.16 & 0.16 & 0.32 \\
\hline Candida glabrata & 0.32 & 0.64 & 0.32 & 0.64 & 0.32 & 0.64 \\
\hline Candida krusei & 0.16 & 0.32 & 0.32 & 0.64 & 0.64 & 2.5 \\
\hline Candida tropicalis & 1.25 & 2.5 & 1.25 & 2.5 & 1.25 & 2.5 \\
\hline
\end{tabular}

\section{Cytotoxic Activity}

The cytotoxicity of the T. erecta EOs was carried out against HepG2 cell lines at different concentrations to determine growth inhibition rate. A dose-response histogram created between the range of 5 and $122 \mu \mathrm{g} \mathrm{mL}-1$ for the EOs of all three parts (Fig. 2) expresses the decreasing number of viable cells with increasing concentrations of EO. The EOs significantly exhibited high cytotoxicity in comparison with the control (untreated cells). The test samples showing cell viability ranging between $33.64 \%$ and $93.1 \%$ at 5.12 to $7.6 \mu \mathrm{g} \mathrm{mL}-1$ were considered to be less active at minimum concentration. In addition, the antiproliferative effect strengthens with an increase in the concentration of the EOs. Maximum apoptosis rate of up to $90 \%$ was observed for the HepG2 cell line at concentrations ranging between 82 and $122 \mu \mathrm{g} / \mathrm{ml}$, with $\mathrm{IC}_{50}$ value from $11.58 \mu \mathrm{g} \mathrm{mL} \mathrm{m}^{-1}$ to $19.86 \mu \mathrm{g} \mathrm{mL}^{-1}$ (Table 3). A much lower amount of viable cells (less than 10\%) were detected at this range of concentrations, which showed the maximum inhibition concentration. These results were in accordance with previous studies performed on $T$. erecta conducted by Gupta and Gupta [6], Vallisuta and Nukoolkarn [25], and Ayyadurai and Valarmathy [26]. Interestingly, the study conducted by [7] for determining the cytotoxic activity of the essential oils of four plants (T. erecta L., Tetradenia riparia, Bidens sulphurea, and Foeniculum vulgare) against six tumor cell lines murine melanoma (B16F10), human colon carcinoma (HT29), human breast adenocarcinoma (MCF-7), human cervical adenocarcinoma (HeLa), human hepatocellular liver carcinoma (HepG2), and human glioblastoma (MO59J, U343, and U251), showed that cancer cells have higher sensitivity to the oil of T. erecta.

This would suggest that, as claimed for the antimicrobial effect, the cytotoxicity of $T$. erecta EO could be ascribed to the lipophilic nature and low molecular weights of the constituents of essential oils that allow them to cross cell membranes, altering the phospholipid layers, increasing membrane fluidity, and leading to leakage of ions and of cytoplasmic content [27]. Accordingly, we can conclude that
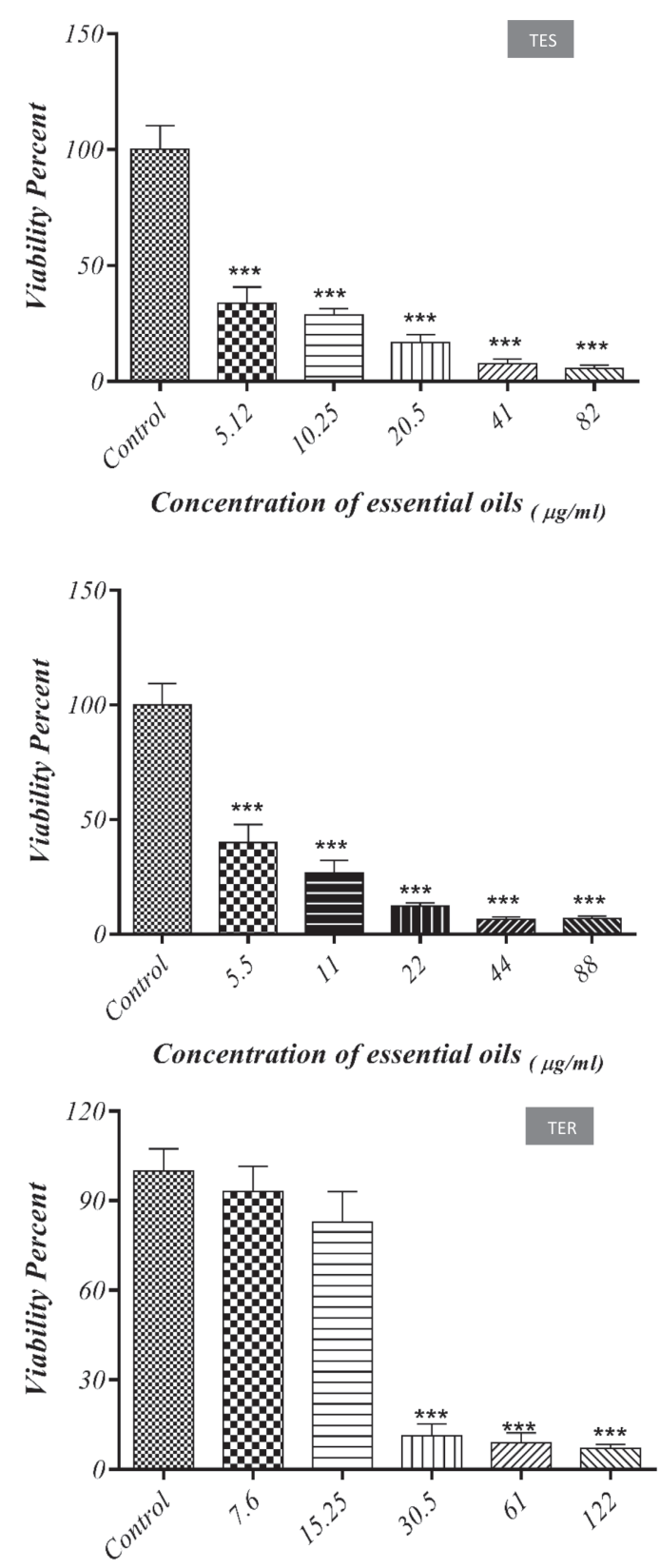

Concentration of essential oils $(\mu \mathrm{g} / \mathrm{ml})$

Fig. 2. Inhibitory effect of $T$. erecta $\mathrm{EO}$ on HepG2 cell growth. The number of viable cells is expressed as a percentage of vehicle control. Mean \pm standard deviation (SD) of 5 independent experiments. 
Table 3. Cytotoxicity of the essential oil of $T$. erecta on HepG2 cells.

\begin{tabular}{|c|c|c|}
\hline$\#$ & Plant part EO & $\mathrm{IC}_{50}(\mu \mathrm{g} / \mathrm{mL})$ \\
\hline 1. & TES & 17.46 \\
\hline 2. & TEF & 11.58 \\
\hline 3. & TER & 19.86 \\
\hline
\end{tabular}

the EOs of $T$. erecta were found to be highly effective against HepG2 cells without affecting normal cells.

\section{Conclusions}

Today an approach has been made to use EOs as a source of new antibiotics. However, the EO components of $T$. erecta and their biological activities are widely documented worldwide. Thus, the role of this plant cannot be neglected as is evident with the present results. Generally, 111 compounds were screened; out of these, more than 60 new EOs were extracted for the first time in this plant, including iso-bergapten, bergapten, (3)-thujanol acetate, sylvestrene, $\alpha$-vetivone, $\beta$-bisabolene, tridecenol acetate, (E)-phytol acetate, $\beta$-atlantol, and $p$-cymenene. The results showed that the chemical composition of $T$. erecta EO varies when compared with the literature chart, depending on the geographical situation, extraction method, environmental factors, and plant organ. The above findings suggest that the EOs of this plant are a good source of antifungal and anticancer agents due to the high concentration of the lipophilic oxygenated terpenoids.

\section{Abbreviations}

GC: Gas chromatography

GC-MS: Gas chromatography-mass spectrometry

GC-FID: Gas chromatography-flame-ionization detection

EO: Essential oil

TES: Shoot of Tagetes erecta

TES-EO: Essential oil of Tagetes erecta shoot

TEF: Flowers of Tagetes erecta

TEF-EO: Essential oil of Tagetes erecta flower

TER: Root of Tagetes erecta

TER-EO: Essential oil of Tagetes erecta root

KI: Kovats' retention indices

RT: Retention time

SDB: Sabouraud dextrose broth

Nys: Nystatin

CFU: Colony-forming unit

\section{Conflict of Interest}

The authors declare no conflict of interest.

\section{Acknowledgements}

The authors are grateful to the deanery of College of Science, Salahaddin University- Erbil, and Dr. Hero M. Ismael for providing yeast strains and assisting for this research work.

\section{References}

1. PRIYANKA D., SHALINI T., VERMA N. A brief study on marigold (Tagetes Species): a review. 2013.

2. DEVIKA R., JUSTIN KOILPILLAI Y. Anti-inflammatory Effect of Bioactive Compounds of Tagetes erecta (Linn.) Flower Extract. 9. 2015.

3. RAVIKUMAR P. Chemical examination and insecticidal properties of Tagetes erecta and Tagetes patula. Asian Journal of Bio Science. 5 (1), 29, 2010.

4. MÁRCIA M.M. MARQUES, SELENE M. MORAIS, ÍCARO G.P. VIEIRA, MARIANO G.S. VIEIRA, ANA RAQUEL. A. SILVA, RAIMUNDO RAFAEL DE ALMEIDA, MARIA IZABEL F. GUEDES. Larvicidal activity of Tagetes erecta against Aedes aegypti. J Am Mosq Control Assoc. 27 (2), 156, 2011.

5. BRIJESH TRIPATHI, ROHIT BHATIA, SURESH WALIA, BIRENDRA KUMAR Chemical Composition and Evaluation of Tagetes erecta (Var. Pusa Narangi Genda) Essential Oil for its Antioxidant and Antimicrobial Activity. Biopestic Int. 8, 2012.

6. PANKAJ GUPTA, ALKA GUPTA, KRATI AGARWAL, PRITI TOMAR, SAURABH SATIJA Antioxidant and cytotoxic potential of a new thienyl derivative from Tagetes erecta roots. Pharm Biol. 50 (8), 1013, 2012.

7. OLIVEIRA, POLLYANNA FRANCIELLI DE ALVES, JACQUELINE MORAIS DAMASCENO, JAQUELINE LOPES OLIVEIRA, RENATA APARECIDA MACHADO DIAS JÚNIOR, HERBERT CROTTI, ANTÔNIO EDUARDO MILLER TAVARES, DENISE CRISPIM Cytotoxicity screening of essential oils in cancer cell lines. Revista Brasileira de Farmacognosia. 5, 183, 2015.

8. LAOSINWATTANA C., WICHITTRAKARN P., TEERARAK M. Chemical composition and herbicidal action of essential oil from Tagetes erecta L. leaves. Industrial Crops and Products. 2018.

9. DASTAN D., SALEHI P., MAROOFI H. Chemical Composition, Antioxidant, and Antimicrobial Activities on Laserpitium carduchorum Hedge \& Lamond Essential Oil and Extracts During Various Growing Stages. Chem Biodivers. 13 (10), 1397, 2016.

10. ADAMS R.P. Identification of essential oil components by gas chromatography/mass spectrometry. Vol. 456. Allured publishing corporation Carol Stream, IL, 2007.

11. PFALLER MICHAEL, CHATURVEDI V., ESPINELINGROFF A., GHANNOUM MAHMOUD, GOSEY L.L., ODDS F.C. Reference method for broth dilution antifungal susceptibility testing of yeasts: approved standard-second edition. CLSI document M27-A2 (ISBN 1-56238-469-4), 22, 2008.

12. RODRÍGUEZ-TUDELA J.L., BARCHIESI F., BILLE J., CHRYSSANTHOU E., CUENCA-ESTRELLA M., DENNING D., DONNELLY J.P., DUPONT B., FEGELER W., MOORE C., RICHARDSON M., VERWEIJ P. E. Method for the determination of minimum inhibitory concentration (MIC) by broth dilution of fermentative 
yeasts. Clinical Microbiology and Infection. 9 (8), i-viii, 2003.

13. BACHA K., TARIKU Y,. GEBREYESUS F., ZERIHUN S., MOHAMMED A., WEILAND-BRAUER N., SCHMITZ R.A,. MULAT M. Antimicrobial and antiQuorum Sensing activities of selected medicinal plants of Ethiopia: Implication for development of potent antimicrobial agents. BMC Microbiol. 16 (1), 139, 2016.

14. ISO -. Biological Evaluation of Medical Devices - Part 5: Tests for In Vitro Cytotoxicity. 2009.

15. CREVELIN E.J. Antifungal activity of the essential oils of plectranthus neochilus (Lamiaceae) and tagetes erecta (Asteraceae) cultivated in brazil. International Journal of Complementary \& Alternative Medicine. 11 (2), 2018.

16. RESMI S., NAIR DIVYA V., SUBHASH ATHULYA, JOSE ROSE, VISHNU V., ZACHARIAH SUBIN MARY Isolation, Characterization and in vitro Pharmacological Activities of Tagetes Erectus Linn. Pharmacognosy Journal. 10 (2), 2018.

17. YASHESHWAR UMAR, SHAHID SHARMA M.P., KHAN WASHIM, AHMAD SAYEED Variation in ornamental traits, physiological responses of Tagetes erecta $\mathrm{L}$. and T. patula L. in relation to antioxidant and metabolic profile under deficit irrigation strategies. Scientia Horticulturae. 214, $200,2017$.

18. MAROTTI I., MAROTTI M., PICCAGLIA R., NASTRI A., GRANDI S., DINELLI G. Thiophene occurrence in different Tagetes species: agricultural biomasses as sources of biocidal substances. Journal of the Science of Food and Agriculture. 90 (7), 1210, 2010.

19. SAHA SUPRADIP, KUNDU ADITI, KUMAR WALIA, SURESH JOSHI Antifungal Acetylinic Thiophenes from Tagetes minuta: Potential Biopesticide. 85, 2012.

20. PESSINI GREISIELE LORENA, DIAS FILHO BENEDITO PRADO, NAKAMURA CELSO VATARU, CORTEZ DIÓGENES APARÍCIO GARCIA Antifungal activity of the extracts and neolignans from Piper regnellii (Miq.) C. DC. var. pallescens (C. DC.) Yunck. Journal of the Brazilian Chemical Society. 16 (6A), 1130, 2005.
21. PADALIA H., CHANDA S. Antimicrobial Efficacy of Different Solvent Extracts of Tagetes erecta L. Flower, Alone and in Combination with Antibiotics. Applied Microbiology: open access. 1 (1), 2015.

22. ROMAGNOLI C., BRUNI R., ANDREOTTI E., RAI M.K., VICENTINI C.B., MARES D. Chemical characterization and antifungal activity of essential oil of capitula from wild Indian Tagetes patula L. Protoplasma. 225, 57, 2005.

23. SALEHI B., VALUSSI M., MORAIS-BRAGA M., CARNEIRO M.F.B., LEAL J.N.P., ALAB COUTINHO, VITALINI H.D.M., KREGIEL S., ANTOLAK D., SHARIFI-RAD H., SILVA M., YOUSAF N.C.C., MARTORELL Z., IRITI M., CARRADORI M., SHARIFI-RAD S.J. Tagetes spp. essential oils and other extracts: Chemical characterization and biological activity. Molecules. 23 (11), 2847, 2018.

24. POLITI F.A.S., QUEIROZ-FERNANDES G.M., RODRIGUES E.R., FREITAS J.A., PIETRO R.C.L.R. Antifungal, antiradical and cytotoxic activities of extractives obtained from Tagetes patula L. (Asteraceae), a potential acaricide plant species. Microb Pathog. 95, 15, 2016.

25. VALLISUTA O., NUKOOLKARN V., MITREVEJ A., SARISUTA N., LEELAPORNPISID P., PHRUTIVORAPONGKUL A., SINCHAIPANID N. In vitro studies on the cytotoxicity, and elastase and tyrosinase inhibitory activities of marigold (Tagetes erecta L.) flower extracts. Exp Ther Med. 7 (1), 246, 2014.

26. AYYADURAI N., VALARMATHY N., KANNAN S., JANSIRANI D., ALSENAIDY A. Evaluation of cytotoxic properties of Curcuma longa and Tagetes erecta on cancer cell line (Hep2). African Journal of Pharmacy and Pharmacology. 7 (14), 736, 2013.

27. RUSSO R., CORASANITI M.T., BAGETTA G., MORRONE L.A. Exploitation of cytotoxicity of some essential oils for translation in cancer therapy. Evid Based Complement Alternat Med. 2015, 1, 2015. 